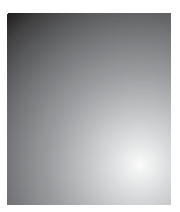

\title{
Teaching Entrepreneurship Students the Practice of INNOVATION: A BRAIN-BASED GUIDED EXPERIENCE APPROACH
}

\author{
Ensinando Estudantes de Empreendedorismo a Praticar \\ Inovação: uma abordagem baseada na experiência guiada no \\ cérebro
}

\begin{abstract}
Ronald Jean Degen
Invited Professor FGV-EBAPE and HSM Educação, Electronic Engineer from IMT São Paulo, Post-graduate in Automation from ETH Zurich, MBA from University of Michigan Ann Arbor, Ph.D. Candidate from ISM Paris, and author of two widely adopted textbooks on entrepreneurship - Rio de Janeiro - RJ - Brasil.E-mail: rjdegen@gmail.com
\end{abstract}

\begin{abstract}
This paper presents a new method for teaching entrepreneurship students to practice innovation and to create high-impact business opportunities. The teaching method is based on the guided experience learning model that was developed by Caine et al. (2009) to develop the executive functions in the brains of learners, and on the innovation framework that was introduced by Verganti (2009). The cognitive perspective of creativity, as explained by Weisberg (2006), is used to show how the practice of innovation can be learned. The model used for the creative process is based on research by Wallas (1926), and on recent neurological findings on the deliberate and spontaneous pathways to creativity (Carson, 2010). The concept of effectual process (SARASVATHY, 2008) provides an approach to the validation of the students' radical innovation ideas.
\end{abstract}

Keywords: Teaching Entrepreneurship. Practice of Innovation. Creativity Process.

\section{Resumo}

Este artigo apresenta um novo método para ensinar estudantes de empreendedorismo a praticar inovação e criar oportunidades de negócios de alto-impacto. $\mathrm{O}$ método de ensino é baseado no modelo de aprendizado através da experiência desenvolvido por Caine et al. (2009) para desenvolver as funções executivas no cérebro dos aprendizes e na estrutura de inovação introduzida por Verganti (2009). A perspectiva cognitiva da criatividade, como explicada por Weisberg (2006), é usada para mostrar como a prática da inovação pode ser apreendida. O modelo usado para o processo criativo está baseado na pesquisa de Wallas (1926) e em recentes descobertas neurológicas sobre os caminhos deliberados e espontâneos para a criatividade (Carson, 2010). O conceito do processo effectual (Sarasvathy, 2008) prove uma abordagem para a validação das ideias de inovações radicais dos estudantes.

Palavras-chave: Ensinando Empreendedorismo. Pratica da Inovação. Processo Criativo. 


\section{INTRODUCTION}

This paper proposes a methodology to teach entrepreneurship students in Brazil to practice innovation, which will allow them to become the high-impact entrepreneurs (also called high-growth entrepreneurs) who will produce competitive products for the home market and for exports, create jobs for the growing population, and accelerate the country's sustainable development. The term high-impact entrepreneurs is used by the Global Entrepreneurship Monitor (Morris, 2011) to designate a very small group of successful entrepreneurs who launch and lead companies with above-average impact in terms of job creation, wealth creation, and the development of entrepreneurial models; although this group represented only $4 \%$ of the entrepreneurs surveyed by the Global Entrepreneurship Monitor (GEM) in sixty countries, they were found to have created close to $40 \%$ of the jobs generated by all the entrepreneurs surveyed.

The methodology presented in this paper complements the proposal by Degen (2009b, 2010b) to create multidisciplinary open entrepreneurship centers in Brazilian universities, in order to promote innovation. These centers are intended to operate independently of the business schools within which they would traditionally be incorporated, and they would therefore allow students, faculty, and alumni from all schools of the university - representing a diverse range of skills and knowledge - to take entrepreneurship courses and interact with each other and with potential investors, customers, and suppliers. To facilitate the implementation of the proposal, Degen (2009a) wrote a textbook for the course, to be made available at the entrepreneurship center.

Drucker (1986) postulated that entrepreneurship is the practice of innovation. As such, he has outlined that it is knowledge-based, and that like any other practice (such as medicine or engineering) it can be learned. However, he also stated that a theory of innovation cannot be developed; instead, he argued, it is sufficient to say when, where, and how to look for innovation opportunities. As a consequence of this lack of a theoretical base for innovation, Drucker, and most other authors on innovation, such as von Hippel (1995), Utterback (1996), and Christensen (2003), have simply ignored the ways in which entrepreneurs practice innovation and how this practice can be learned. Instead, they have concentrated on ways to systematically look for innovation opportunities.

Recently, however, some attempts have been made to describe the practice of innovation and to identify how this might be learned. Verganti (2009) explained that an individual's ability to innovate and create radical high-impact innovations (such as Steve Jobs with the Apple II, iPod, iPhone and iPad) lies in his or her personal culture. Verganti provided many examples of entrepreneurs who practiced innovation based on their personal culture, but he failed to explain how they learned this practice of innovation. He simply postulated that individuals within certain cultures (or knowledge) practice innovation.

This paper builds on the postulate, presented by Verganti (2009), that knowledge is required to innovate. The proposition for the present research is to fill the gap left by Drucker (1986) and to complete the postulate presented by Verganti, by formulating a possible methodology: teaching entrepreneurship students how to practice innovation by acquiring the necessary knowledge. The essence of this methodology is to motivate and coach students to learn by total immersion in a specific business and all that directly or indirectly influences (or may influence) this are of business. By learning about the business, the student will acquire the necessary knowledge base to intuit what people could want. Afterwards, if the students are properly motivated by their intuition of an innovation, they will use what Sarasvathy (2008) termed effectuation logic to transform the intuition into a meaningful business proposition.

\section{Brazil Needs High-impact ENTREPRENEURS}

Brazil has a growing population of over 192 million citizens, that include over 10 million poor with an average income of less than two US dollars per day (The World Bank, 2011). The country urgently requires more high-impact entrepreneurs to create jobs, create wealth, and to consolidate and grow its economy. Unfortunately, the Brazilian business schools that have been teaching entrepreneurship over the last three decades have not had the expected impact on high- 
-impact entrepreneurship; according to a study by the Global Entrepreneurship Monitor (Greco et al., 2011), Brazilians are highly entrepreneurial, but the innovation content in their new business ventures is negligible.

Degen (2009b) suggested that the main reason for the lack of innovation in new business start ups is that students who participate in entrepreneurship courses (in business schools) do not have access to the required technical knowledge to innovate, or do not have contact with people who can supply this knowledge. Conversely, many people who have the technical knowledge to innovate in other courses at the universities lack the basic business skills to start up a new business. To compensate for this deficiency and to bring people with complementary skills and knowledge together, Degen (2009b) proposed that universities create multidisciplinary open entrepreneurship centers to promote innovation.

For these entrepreneurship centers to be effective, the courses that are provided have to go beyond the traditional teaching of entrepreneurship in terms of how to create, plan, start up, finance, develop, and manage a new business. The courses will have to teach students how to acquire the necessary knowledge to effectively practice innovation, using the methodology described in this paper (or some variation of this methodology).

\section{Acquiring a Personal Knowledge Base}

Dewey (1998) noted that the acquisition of knowledge occurs mainly by processing existing experience in a chosen field to assist creativity in future experiences. To acquire a personal knowledge base in order to innovate in their chosen business field, entrepreneurship students must intensively experience the business and all that directly or indirectly influences it.

In order to experience the business effectively, students need to acquire a sense of purpose that has been defined by McClelland (1967) as a high need to achieve (N-Arch.): this is a personal challenge that the students feel an intrinsic commitment to overcome. This high need to achieve has to become a personal aspiration that generates a degree of excitement, which will then energize the students to search for the meaning of their experiences. Unfortunately, only a minority of entrepreneurship students have the high need to achieve that is required to intensively live an experience and therefore to acquire the necessary knowledge to practice innovation.

Gopnik et al. (1999) defined the search for meaning of experiences as the explanatory drive of the human brain: this consists of the need to identify, name, and organize the elements of experiences into meaningful patterns that build up knowledge. They explained that the explanatory drive is the need to look beyond the surface facts of the world and to infer its deepest patterns, to search for an underlying cause of events, and to attempt to figure out the nature of things. This search for meaning by using the organization and categorizing of information from experiences was defined by Caine et al. (2009) as the processing and patterning of experiences.

\section{Active Processing Experiences and the USE of the Brain's ExeCUtive FUNCTIONS}

When students naturally acquire an intrinsic commitment to a personal aspiration (a high need to achieve per McClelland, 1967) they become excited and energized in their processing and patterning of the business experience. Students who are energized by the challenges of the business experience are fully living and capitalize on the experience in what Caine and Caine (1990, 1991) defined as active processing of the experience. This is the art of digesting, thinking about, reflecting on, and making sense of experiences, and so consolidating knowledge.

To actively process a business experience, students require an intensive experience. They have to feel deeply challenged by the questions raised from living the experience. They must feel compelled by their high need to achieve to formulate ideas and answers to the questions to reflect on the feedback to their ideas and answers, and to search constantly for better ideas and answers. These reflections, and the search for new ideas and answers, will solidify and expand their knowledge base in the selected business field. This level of intensity also helps the students in the processes of conceiving, interpreting, and applying their growing knowledge base to overcome the challenges of the business. 
The active processing of experiences makes the students use the executive functions of their brains. These functions are largely housed in the front of the brain, in what is known as the prefrontal cortex. These functions are responsible for the human ability to plan and organize thinking, use reason, engage in risk assessment, make sense of ideas and behavior, multitask, moderate emotion, work with longer time horizons, think critically, access working memory, and reflect on personal strengths and weaknesses (LeDoux, 2002; Caine et al., 2009). The skills that use the brain's active functions are essential for students to actively process experiences.

Unfortunately, the experiences that teach students to use their brains' executive functions are being lost in the present age of instant information. The internet, and other media, supply an almost infinite number of facts to students. The students are rarely challenged to think critically, analyze content, evaluate what is happening, or make their own intelligent decisions. Television, video games, internet, social media, and search engines provide students with entertainment, excitement, and information, without the need for the type of reflection that helps to develop the executive functions of their brains (Caine et al., 2009). As a consequence, many students lack the patience or motivation to reflect on the answers they find in the internet, and so don't exercise the executive functions of their brains (Small and Vorgan, 2008; Carr, 2010). These students simply don't develop their skills sufficiently to use the executive functions to search for meaning in experiences and to acquire the necessary knowledge base to practice innovation.

\section{Reaching Flow}

Csikszentmihalyi (2008) termed living an optimal experience as the equivalent to Caine et al. (2009)'s active processing of the experience. Students who are living an optimal experience, according to Csikszentmihalyi, experience flow, and enjoy the business experience they are living so much that they forget everything else and continue working on its challenges - sometimes at a substantial personal cost - for the sheer sake of acquiring more knowledge and finding new solutions.
For entrepreneurship students to live an optimal experience and stay continuously in flow, they must be intrinsically motivated by their high need to achieve. They must feel compelled to actively process the business experiences in their selected field to achieve the aspired outcome for their business venture. Their personal goals have to be ambitious, but not overly ambitious, in order to avoid frustration or demotivation. Each time a student overcomes a hurdle ( $\mathrm{H} 1$ in Figure 1$)$ they need to aim for the next hurdle (H2 in Figure 1), similar to a continuous obstacle race. If a hurdle is too difficult (D in Figure 1) because the students have not acquired yet the necessary knowledge to overcome it, they become frustrated and may abandon the quest for the final goal. If the hurdle is too easy ( $\mathrm{E}$ in Figure 1 ) to overcome, the students are not challenged enough by the business experience, and may become demotivated. Without motivation, students usually do not acquire the necessary knowledge to practice innovation.

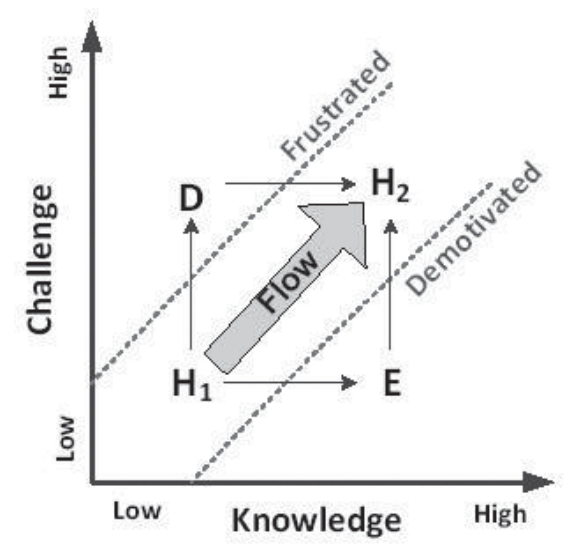

Figure 1: Living an optimal experience and reaching flow Source: Adapted from Csikszentmihalyi (2008, p. 74)

\section{Creative thinking}

Creative thinking is the essence of the practice of innovation and is simply ordinary thinking that has produced an extraordinary outcome (Simon, 1986). This interpretation of creative thinking is called the cognitive perspective of creativity (Weisberg, 2006), where creative thinking is constructed from the basic cognitive activities of ordinary thinking: memory (remembering), planning (anticipation and correcting of potential errors), logic reasoning (both induction and deduction), comprehension (of verbal and nonverbal 
information), and judging (whether an anticipated action will be accepted).

Ordinary thinking is firmly rooted in a person's past experiences, and some of the most creative ideas come from making associations between remote and seemingly disconnected ideas and concepts that were learned in past experiences (Mednick, 1962). Thus, both ordinary thinking and creative thinking (that is, ordinary thinking that produces extraordinary outcomes) are rooted in accumulative past experiences (Weisberg, 2006). This suggests that entrepreneurship students can think progressively more effectively or more creatively about a business venture as they accumulate more experiences.

Thinking has always been an important aspect of human beings. For this reason René Descartes wrote his famous phrase "cogito ergo sum" (I think therefore I am); this was inverted by Damasio (2006) in Descartes' Error to "I am, therefore I think" or in modern terms "I have a brain (memory), therefore I think." Damasio and other researchers (LeDoux 2002; Squire and Kandel 2009; Damasio 2006, 2010) disagreed with Decartes, and suggested that thinking is not the defining factor in human identity. They explained that the human personality requires the ability to remember past experiences and awareness of the subjects that are being thought about, and that personal knowledge, stored in memory, directs all activities, including ordinary and creative thinking.

\section{Creative Thought Process}

One of the first models for creative thought process was presented by Wallas (1926), who in The Art of Thought based his knowledge on written accounts by artists and scientists. He described the creative thought process as having four stages. The first is preparation, which consists in gathering background information and then exploring and focusing on the problem to be solved. The second is incubation, which involves internalizing the problem and then taking a break from actively thinking about it. The third is illumination, which is a moment of insight in which creative solutions to the problem pop into conscious awareness. The fourth is verification, which involves judging the appropriate- ness of the solution or idea, elaborating on it, and then actually applying it to the original problem.

Carson (2010) complemented the creative process that had been described by Wallas (1926), and developed it further, using recent brain research to describe two pathways to creativity: the deliberate pathway and the spontaneous pathway (see Figure 2). The deliberate pathway involves moving deliberatively and consciously toward a creative solution, step-by-step, and sensing when the solution is closer; the spontaneous pathway allows creative solutions to be generated at an information processing level in the brain (below conscious awareness) so that the solutions (when they appear to meet a certain level of appropriateness) push forward into consciousness as an "aha!" moment. Unlike the deliberate pathway, the spontaneous pathway does not entail a sense of coming closer to a solution, until the insight bursts forth. (Carson, 2010)

\section{Stages of the creative thought process}

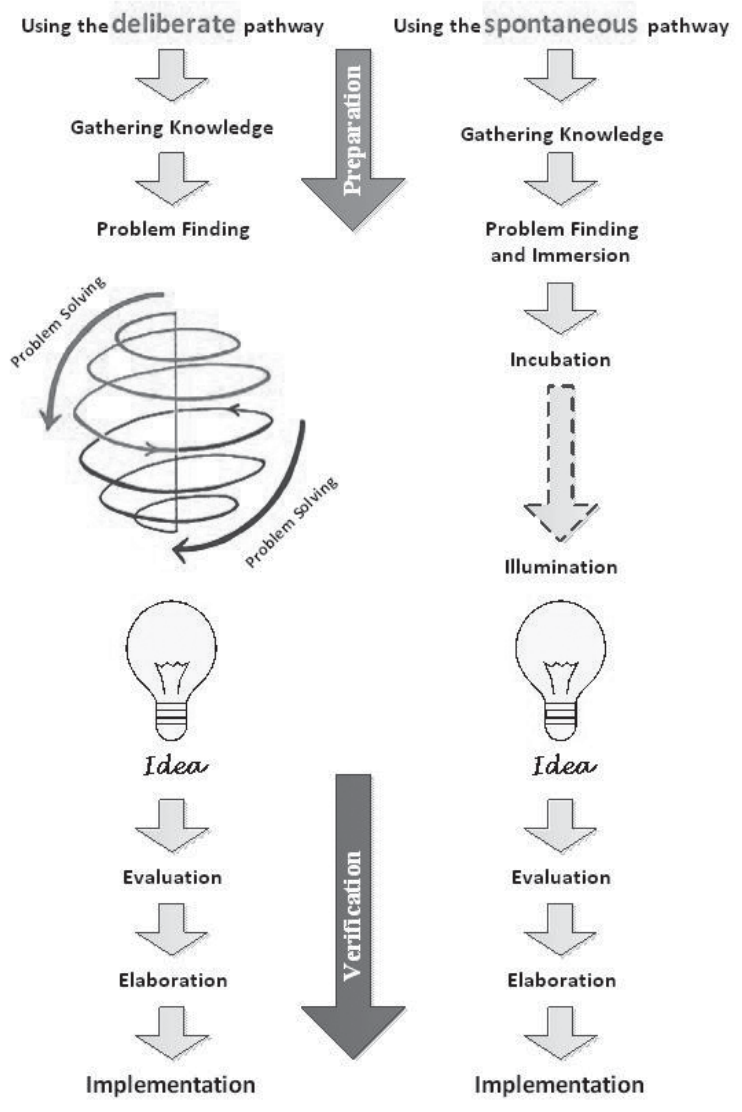

Figure 2: Stages of the creative thought process

Source: Adapted from Carson (2010, p. 62) 
Preparation is the first stage of Wallas' (1926) creative thought process, and is the key to accessing both of the pathways described by Carson (2010). Entrepreneurship students who want to generate creative ideas need to absorb as much knowledge as possible on their chosen business field, and in as many related (or even unrelated) fields that they can. They must therefore take to heart Louis Pasteur's famous quote "le hazard favorise lésprit prepare" (chance favors the prepared mind), and build on the acquired knowledge to generate ideas and select from these ideas the most promising ones for validation. This means moving from the preparation phase (using one of the pathways illustrated in Figure 2) in order to create an idea, and then entering the validation phase.

\section{Effectual Logic}

Radical new ideas for products or services, which are the basis for high-impact entrepreneurship, cannot be validated using casual logic. A reasonable prediction of the future is needed in order to control casual logic and to permit the writing of a credible business plan (necessary to validate the new idea and the business venture required to realize it). With a radical new idea this prediction is not possible, because the new business venture will be breaking new ground. In this case, the solution is to use effectual logic, which focuses on finding ways to control the future when it cannot be predicted. This approach explores and tests the business horizon, takes advantage of unexpected events by transforming them into opportunities, and actively creates a new future for the business venture.

Ideas for radical innovation face three obstacles, as described by Sarasvathy (2008):

a) It is impossible to calculate the future consequences of the innovation.

b) Preferences are neither given nor well-ordered for the innovation.

c) The elements of the environment to pay attention to (and to ignore) in order to influence the innovation, are unclear.

Under these conditions the only approach is to evoke creativity and use transforming tactics to validate the idea. This can be achieved by using a trial-and-error method known as the effectual process. The effectual process uses five core principles for validating radical new products or services (Sarasvathy, 2008), as described here:

a) Bird-in-hand principle. Begin with what is available, rather than waiting for the perfect opportunity. Action is based on what is readily available: identity, knowledge, and personal networks.

b) Affordable loss principle. Evaluate opportunities based on whether the downside is acceptable; rather than on the attractiveness of the predicted upside.

c) Crazy-quilt principle. Form partnerships with people and organizations who are willing to make a commitment to jointly create the future (in terms of product, firm, or market), rather than basing partnerships on competitive analyses or strategic planning.

d) Lemonade principle. Leverage contingencies by embracing surprises that arise from uncertain situations, remaining flexible rather than tethered to existing goals.

e) Pilot in the plane principle. Each of the previous principles implies the logic of non-predictive control. The effectuation process suggests focusing on the controllable aspects of an unpredictable future, using the following logic: to the extent that we can control the future, we do not need to predict it.

The implication of these principles, in terms of validating ideas of radical innovations, is straightforward, and points to the need to develop prototypes of the radical innovations as soon as possible at affordable costs, rather than waiting for perfection (which may eventually lead the innovation to become irrelevant). These ideas can then be tested in the market with potential customers, suppliers, and distributors. If positive, feedback can be used to improve the idea; or if the feedback is negative the idea can be abandoned, taking the previously calculated affordable loss into account.

The use of effectual logic to validate a radical innovation (i.e. effectual process) requires a very strong determination to succeed. Entrepreneurship students with a high need to achieve, who are intrinsically motivated by their innovation idea, will have this determination. This is necessary, because they are breaking new ground, and will be faced with various types of skepticism and difficulties. The innovators 
will need to expend substantial effort toward redoing, adapting, perfectioning, and convincing before the idea is accepted. Lindblom (1959) has termed this effort the science of muddling through.

\section{Guided Experience Learning Model}

The guided experience learning model, which is used to teach students ways to actively process experiences, was developed by Caine et al. (2009), based on brain learning principles. The model outlines three fundamentally interconnected elements of effective teaching:

a) The first is relaxed alertness. The optimal emotional climate for learning is defined as consisting of low threat and high challenge for the students, so that they feel competent and confident, and are intrinsically motivated.

b) The second is orchestrated immersion in complex experience. The concept of this optimal opportunity for students to learn is based on the fact that the human brain learns through experience: by making connections between what is experienced and what the experience means.

c) The third is active processing of experience. The optimal way to consolidate learning occurs when students obtain ongoing feedback and continuously reflect on the experience they are living. This allows them to solidify and expand their knowledge base fully, using the capability of the human brain to better remember things that are meaningful.

Caine et al. (2009) described the application of the model for teaching students, as straightforward, and they outline five key phases:

1. The first phase is creating an initial sense of felt meaning (felt meaning engages thoughts, emotions, senses, and the whole body). In this phase, the students are driven by a sense of purpose and meaning toward a personal goal. This drive is crucial for peak performance.

2. The second phase is forming preliminary connections to new subject matter. In this phase, the students are encouraged, through preliminary exploration, to buy in to the field that they want develop, so that they can decide on how they want to explore it.
3. The third phase is deep exploration through research and projects. In this phase the students engage with the chosen field through continuous improvement, refining, and processing of what they are learning.

4. The fourth phase is creating a product. In this phase the students demonstrate the unique aspects of the field being investigated.

5. The fifth phase is consolidation. In this final phase the students identify what they have learned from the project.

Caine et al. (2009) recommended that the teacher conducting the guided experience motivate active processing of the experience by the students throughout all phases, with particular attention paid to the third phase. To achieve this, the teacher must, in an engaging and motivating fashion, use open-ended questions, guiding comments, and direct instruction when needed. The teacher should constantly praise and encourage the efforts made by the students to reflect on the experience and to search for new ideas and answers, in order to induce the students to actively process the experience and so consolidate their growing knowledge base. This role of the teacher will work only if an authentic partnership with the students has already been established in an optimal emotional climate for learning (i.e. relaxed alertness).

\section{Teaching the Practice of Innovation}

The new method for teaching entrepreneurship students to practice innovation and to create high-impact business opportunities, as outlined here, is based on the guided experience learning model that was developed by Caine et al. (2009) and follows the five phases that were discussed above.

In the first phase, the teacher must create an initial sense of felt meaning in the students by a facilitating a global experience. This is a relative engaged experience that involves the students in multiple ways, helps them to become interested in practicing innovation, and coveys the feeling of meaning that is required to find an innovation. The global experience must also show that the practice is knowledge based and can be learned (as outlined by Drucker, 1986). 
An effective example of a global experience in innovation is the extraordinary story of Steve Jobs, who used his personal knowledge to create the iPod, iPhone, and iPad (Isaacson, 2011). Jobs' history of successes illustrates two important conclusions about innovation (Verganti, 2009). The first is that radical innovation - albeit risky - is one of the major sources of long-term competitive advantage. The second is that people do not buy things; rather, they buy meanings. The meaning of things provides the profound emotional, psychological, and sociocultural reasons for people to use them, and complements any rational utilitarian reasons for their use. This second conclusion suggests that entrepreneurship students have to look for innovations beyond features, functions, and performance, and to understand the real meanings that users give to things.

The two-dimensional framework developed by Verganti (2009) can be used to explain the path that Jobs took to create radical innovations (Figure 3 ). The first dimension is product performance and the second is the meaning of the product to customers. The framework shows the three possible paths (or combinations) to innovation. The first path, market-driven innovation, is the most common, and is promoted by most researchers (see von Hippel, 1995; Utterback, 1996; Christensen, 2003; Christensen \& Raynor, 2003; Christensen et al., 2004). This path consists of researching customers' needs for a product and making incremental performance improvements and adaptations to the evolution of customers' meaning. The second path, technology-driven innovation, consists of making radical improvements to the performance of a product alongside the introduction of new technology. The third path, design-driven innovation (as named by Verganti, 2009), consists of creating of creating a new meaning for a product by redesigning both the product and the experience that customers have with it. In some cases technology-driven and design-driven innovations combine to create a breakthrough new product (designated in Figure 1 by a star).

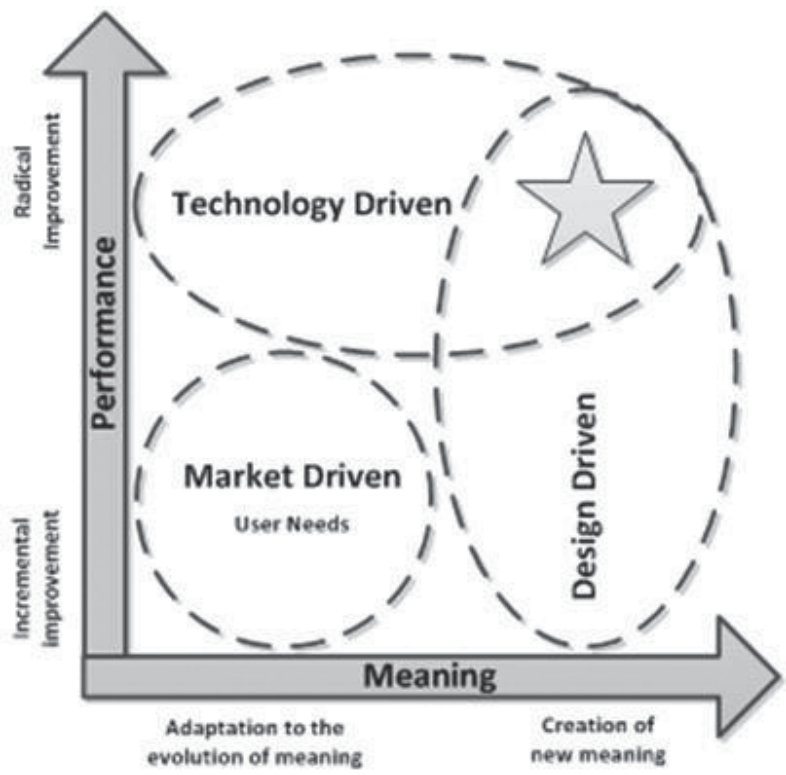

Figure 3: Paths to innovation

Source: Adapted from Verganti (2009, p. 55)

The technology-driven and the design-driven innovations can be defined as pushing innovations: rather than using research on customer needs to develop a product (as in market-driven innovation), pushing innovations propose a breakthrough vision of the product to potential customers. When such a proposal is successful and people embrace the product (such as Jobs' innovations of iPod, iPhone, and iPad), the entrepreneur gains significant long-term competitive advantage. Entrepreneurs who create such products are generally - like Jobs - high-impact entrepreneurs.

The story of Jobs and the iPod starts with the original breakthrough by Sony that created the portable music payer industry with the Walkman (Figure 4). The innovations that followed the Walkman were all technology-driven and consisted of substituting the original cassettes with compact disks and later with flash memory, as used in contemporary portable music players such as the Sony MP3. The iPod, however, was a radical design-driven innovation that dramatically improved existing MP3 players. Jobs achieved this by designing a completely new user experience: he simplified the design, simplified its use, added the facility to organize its music library externally (with iTunes), provided easy access to music (with the online Apple Store), and created unique buying experiences (with the Apple Stores). With this radical design-driven inno- 
vation he created a new meaning for the iPod without any contributing significant technological improvement.

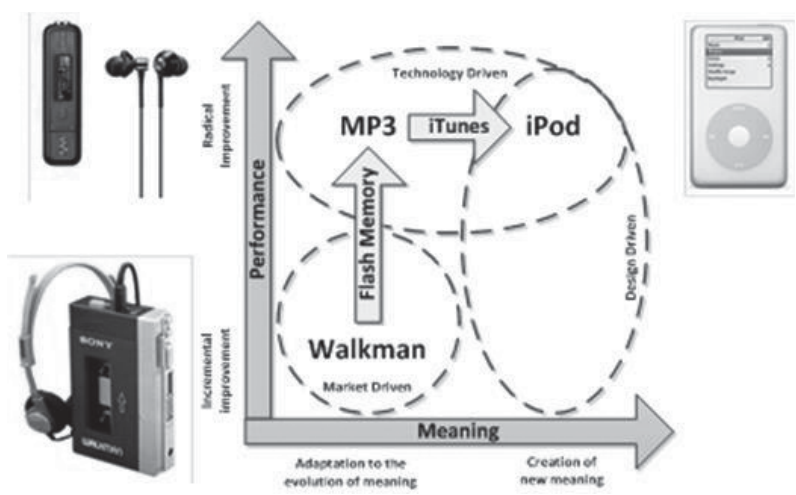

Figure 4: The path of design-driven innovation that Jobs took to create the iPod

Source: Author, based on Verganti (2009, p. 55)

Jobs repeated the same design-driven innovation path for smartphones (with the iPhone) and for computer tablets (with the iPad). Also, in these innovations he dramatically improved the products, by designing completely new user experiences that gave a radical new meaning to these products. Jobs' simple innovation idea was to create simple and user-friendly experiences for the customers who used portable music players, smartphones, or tablet computers. With this idea he created a completely new meaning for these products.

Another notable global example of innovation based on personal knowledge was the radical design-driven innovation of a Swiss company, with the introduction of Swatch (a line of relatively inexpensive and fashion-driven watches) into the traditional electronic watch industry (Figure 5). The Swatch watches were both basic and fashionable, and they simply showed the time. These watches dispensed with all the features that had been introduced by the technology-driven innovations led by the Japanese companies (like Casio, Citizen, and Seiko), even though the new features that resulted from these innovations had significantly enhanced performance and positioned watches as sophisticated instruments. The disruptive technology-driven innovations of the electronic watches made by the Japanese companies forced the Swiss mechanical watch industry (which could not match the performance and features of their Japanese competitors) to reposition their watches as expensive luxury items and status symbols.

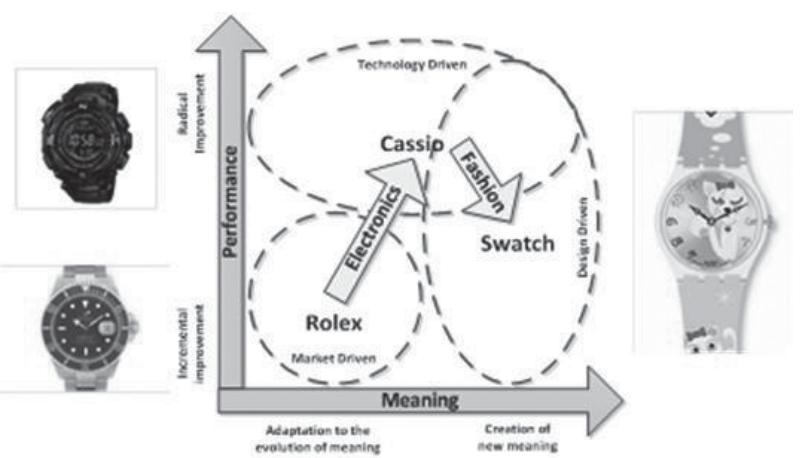

Figure 5: Examples of technology-driven innovation (Casio) and design-driven innovation (Swatch) in the watch industry. Source: Author, based on Verganti (2009, p. 55)

Swatch's innovation idea was to transform watches from sophisticated instruments into almost discardable fashion items. This new meaning of watches as fashion wardrobe items caught on with consumers (especially women), who quickly became accustomed to buying Swatch watches as they would buy any fashion accessory: on impulse or to match a particular outfit.

In relation to these two examples, students should be made aware that the two important sources for radical innovation ideas are research centers (for technology-driven innovations) and interpreters (for design-driven innovations). The latter are individuals or organizations that research how people give meaning to things and that simultaneously influence, with their creations, sociocultural models as well as people's meanings, aspirations, and desires (Verganti, 2009).

Steve Jobs was strongly influenced, in his design-driven innovation, by his attendance at the annual Design Conference in Aspen, were he was exposed to the spare and functional design of the German Bauhaus movement. The style championed by this movement made no distinction between fine art and applied industrial design (Isaacson, 2011), and it taught that design should be simple yet have an expressive spirit. This approach emphasized rationality and functionality by employing clean lines and simple forms. The influence of this interpreter can be seen in everything that Jobs created: including products, services, stores, and the Apple campus.

Swatch adopted a similar approach, by copying the meaning of fashion wardrobe accessories for consumers. They copied the design-driven innovations of these interpreters (including the prices of the fashion accessories industry) to position the Swatch watches 
as fashion items to the same consumers. Japanese watch manufacturers, on the other hand, focused only on technology-driven innovation, transforming their watches into increasingly sophisticated and complicated instruments. They delighted technology fans, but eventually lost appeal among the majority of consumers (especially women) who wanted to know the time without paying for or wearing clumsy (and, arguably, ugly) black instruments.

The discussion of these (or similar) global experiences in innovation can be used to engage students in choosing a business field and exploring their own innovation ideas. The global experiences presented by the teacher should be simple and easy for students to relate to (as in the examples of Jobs and Swatch), rather than presented in lectures that inundate students with facts or information that distract from the innovation ideas. If correctly motivated, students will ultimately, and spontaneously, choose a business field and start accumulating knowledge on it while searching for innovation ideas.

In the second phase, the teacher must encourage students to form preliminary connections to their chosen business field. This exploration can occur via an initial exploration and buy in of the relevant business experience, so that the students can determine how they want to explore the experience to identify innovation ideas. Students will be encouraged to use Verganti's (2009) framework (Figure 3) to organize their search for innovation ideas. Once they have decided and have expressed their commitment to the experience (and to acquiring the necessary knowledge to practice innovation) the teacher will start guiding them in the experience.

In the third phase the teacher will guide the students to deeply explore, through research, the business experience, and to start thinking about innovation ideas and projects. Students will become familiar with cognitive perspectives on creativity (Weisberg, 2006) and the creative thought process (Figure 2; Carson, 2010). The teacher will use encouragement, guiding comments, open-ended questions, and direct instruction to ensure that students remain committed and focused (so that the students actively process the experience). Through this process, students will build and consolidate their knowledge base, start practicing innovation, and conceive innovation ideas. Peer reviews will be used to determine the feasibility of these ideas (these reviews will be undertaken in class with the assistance of the teacher). The ideas that pass this preliminary evaluation will move to the fourth phase, where they will be assessed by potential customers to determine their viability and acceptance.

Unfortunately, not all students in the third phase will have the high need to achieve that is necessary for them to be intrinsically motivated. Without this motivation, it is unlikely that they will live an optimal experience and so reach flow. These students must therefore be encouraged to explore less innovation-dependent business opportunities or to join and support other students in their quest for innovation ideas. Most successful business ventures have been formed by the association of two or more entrepreneurs, who have supported and complemented each other: examples include Steve Jobs and Steve Wozniak (Apple); Larry Page and Sergey Brin (Google); and Bill Gates and Paul Allen (Microsoft). The main reason for the proposal by Degen (2009b, 2010b) to create multidisciplinary open entrepreneurship centers is to encourage the association of students with complementary skills, who can support and complement each other in the development of a business venture.

In the fourth phase, teachers will encourage students to transform their innovation ideas into a product or service. This is an important phase for the students, as it allows them to test the viability of realizing the ideas. The ideal approach is to build a working model that can be tested with potential customers. At this phase, the students have to use effectual logic and transforming tactics to validate the innovation with potential customers (as proposed by Sarasvathy, 2008). If the response of the potential customers is positive, the customer input can be used to improve the idea and to create a plan to realize the venture; if the feedback is negative the idea can be abandoned in favor of new ideas, taking the previously calculated affordable loss.

In the fifth phase, teachers will orient students in writing a comprehensive business plan, which will be based on the students' newly acquired knowledge base (in terms of the field and the feedback of potential customers). When the business plan is complete and meets the required standards, the teacher will help students to find angel investors (if these are needed) in order to finance the start-up of the business. 
The method was described above in consecutive phases: however, many innovation ideas will be conceived in the third phase and fourth phase that will not survive validation assessment. When this is the case, the students will be required to stay in the fourth phase and improve the idea, or return to the third phase and continue searching for new innovation ideas (Figure 6).

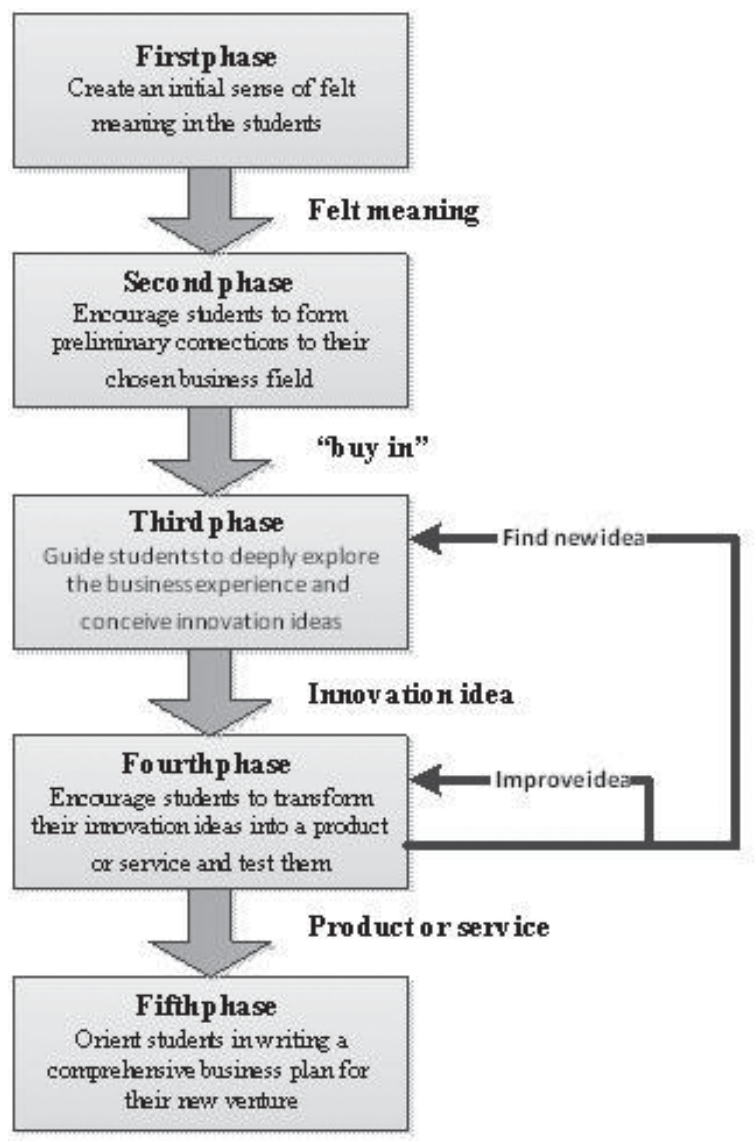

Figure 6: The five phases of the method for teaching entrepreneurship students to practice innovation Source: Elaborated by the author

\section{Validation and Conclusion}

The proposed method for teaching entrepreneurship students to practice innovation has been tested (in a limited and rudimentary form) by the author, in the context of open entrepreneurship courses that were conducted at a university in Brazil that did not have a business school. The students were from all faculties (although predominantly from technical schools) and had expressed a desire to learn how to start up or improve their own business. The success of these courses, as measured by the high number of new business ventures started by the students-and some of these with very creative innovations (some students became high-impact entrepreneurs) - indicates that the method merits further research and more elaborate tests for final validation. This paper was written to motivate entrepreneurship professors to engage in further research into teaching the practice of innovation and to perform more elaborate tests on the validity and effectiveness of the proposed method, in the context of entrepreneurship courses.

This paper also indirectly identifies a deficiency in the existing teaching of entrepreneurship. Most entrepreneurship textbooks focus on how to evaluate new business ventures, how to build business plans for financing, and how to start up a business. They tend to only lightly discuss where to find ideas for innovations, and seldom identify how students can learn the practice of innovation (that is, ways to acquire a sufficient knowledge base to practice innovation, as postulated by Drucker, 1986). Perhaps the only textbook at present to address this at present is by Baron and Shane (2008), who raised the issue that knowledge acquired by individuals from experience is important for identifying business opportunities. They explained that information acquired from experiences is important, but only if the individual can (using what they termed cognitive framework) visualize in the information as a business opportunity.

This paper has identified another important factor for teaching entrepreneurship: that only a minority of the would-be entrepreneurs who enroll in entrepreneurship courses have the high need to achieve that is required to live an optimal experience, acquire the personal knowledge base needed to practice innovation, and use the effectual process to create a successful innovation. However, only these students are likely to become high-impact entrepreneurs. The majority, who don't have a high need to achieve, will either give up or settle for a more simple business opportunity. The teachers of entrepreneurship courses must therefore be prepared to deal fairly will all of their students, independent of the methodology that they use in class. 


\section{REFERENCES}

BARON, R. A.; SHANE, S. A. Entrepreneurship: a process perspective. Mason, $\mathrm{OH}$ : Thomson, 2008. (Original work published 2005)

CAINE, R. N.; CAINE, G. Understanding a brain-based approach to learning and teaching. Educational

Leadership, 48(2), 66-70. 1990.

CAINE, R. N.; CAINE, G. Teaching and the human brain. Alexandria: Association for Supervision and Curriculum Development, 1991.

CAINE, R. N. et al. 12 brain/mind learning principles in action: developing executive functions of the human brain (2nd ed.). Thousand Oaks, Cl: Corwin Press, 2009. (Original work published 2005)

CARR, $N$. What the internet is doing to our brains: the shallows. New York: W. W. Norton, 2010.

CARSON, S. Your creative brain: Seven steps to maximize imagination, productivity, and innovation in your life. San Francisco: Jossey-Bass, 2010.

\section{CHRISTENSEN, C. M. The innovator's dilemma:}

the revolutionary book that will change the way you do business. New York: Harper Business Essentials, 2003.

(Original work published 1997)

CHRISTENSEN, C. M.; ANTHONY, S. D.; ROTH, E. A. Seeing what's next: using the theories of innovation to predict industry change. Boston: Harvard Business School Press, 2004.

\section{CHRISTENSEN, C. M.; Raynor, M. E. The innovator's} solution: creating and sustaining successful growth. Boston: Harvard Business School Publishing, 2003.

CSIKSZENTMIHALYI, M. Creativity: flow and the psychology of discovery and invention. New York: Harper. 1997a. (Original work published 1996)

CSIKSZENTMIHALYI, M. Finding flow: the psychology engagement with everyday life. New York: Basic Books, 1997b.

CSIKSZENTMIHALYI, M. Flow: the psychology of optimal experience. New York: Harper, 2008. (Original work

published 1990)
DAMASIO, A. Descartes' error: emotion, reason, and the human brain. New York: Putnam. 2006. (Original work published 1994)

DAMASIO, A. Self comes to mind: constructing the conscious brain. New York: Pantheon Books, 2010.

DEGEN, R. J. O empreendedor: fundamentos da iniciativa empresarial [The entrepreneur: Fundamentals of free enterprise]. São Paulo: McGraw Hill, 1989.

DEGEN, R. J. Empreendedorismo: uma filosofia para o desenvolvimento sustentável e a redução da pobreza [Entrepreneurship: a philosophy for sustainable development and poverty reduction]. Revista de Ciências da Administração [Journal of Management Sciences], Florianópolis, 10(21), 11-30, 2008.

DEGEN, R. J. O empreendedor: empreender como opção de carreira [The entrepreneur: Entrepreneurship as a career option]. São Paulo: Person Education, 2009a.

\section{DEGEN, R. J. Open entrepreneurship centers in}

Brazil: to promote sustainable development and poverty reduction (Monograph n. 50), 2009b. Retrieved from: $<$ http://econpapers.repec.org/paper/pilwpaper/50.htm>. Accessed on: October 24, 2013.

DEGEN, R. J. Curso de empreendedorismo para promover o desenvolvimento sustentável e a redução da pobreza [Entrepreneurship curse to promote sustainable development and reduce poverty]. In: LOPES, R. M.

A. (Trans.), educação empreendedora: conceitos, modelos e práticas [Entrepreneurial education: Concepts, models and practice]. Rio de Janeiro: Elsevier, 2010a. p. 207-230.

DEGEN, R. J. Teaching entrepreneurship students to become knowledge-agents for innovation (Monograph n. 64), 2010b. Retrieved from: < http:// econpapers.repec.org/paper/pilwpaper/64.htm $>$. Accessed on: October 24, 2013.

\section{DEGEN, R. J. Review of the current knowledge of} brain-/mind-based learning to present the optimum climate for, and the guided experience approach to teaching (Monograph n. 73), 2011. Retrieved from: $<$ http://econpapers.repec.org/paper/pilwpaper/73.htm>. Accessed on: October 24, 2013. 
DEWEY, J. Experience and education. Indianapolis: Kappa Delta Pi, 1998. (Original work published 1938)

\section{DRUCKER, P. F. Innovation and entrepreneurship:} practice and principles (Perennial Library ed.). New York: Harper \& Row, 1986. (Original work published 1985)

GOPNIK, A.; MELTZOFF, A. N.; KUHL, P. K. The scientist in the crib: minds, brains, and how children learn. New York: Perennial, 1999.

GRECO, S. M. D. S.; FRIEDLAENDER Junior, R. H.; TAMADA Neto, M.. Empreendedorismo no Brasil 2010. 2011. Retrieved from GEM website: <http://www. gemconsortium.org/docs/download/451>. Accessed on: October 24, 2013.

ISAACSON, W. Steve Jobs. New York: Simon \& Schuster, 2011.

LINDBLOM, C. E. The Science of "muddling through". Public Administration Review, 19(2), 79-88, 1959.

MADNICK, S. A. The associative basis of the creative process. Psychological Review, 69(3), 220-232, 1962.

MACCLELLAND, D. The achieving society. New York: The Free Press, 1967. (Original work published 1961)

MORRIS, R. 2011 high-impact entrepreneurship report. 2011. Retrieved from GEM website: < http://www. gemconsortium.org/docs/download/295>. Accessed on:

October 24, 2013.

SARASVATHY, S. D. Effectuation: elements of entrepreneurial expertise. Cheltenham, UK: Edward Elgar, 2008.

SIMON, H. A. Frontiers in creative and innovative management. Cambridge, MA: Ballinger, 1985. (R. I. Kuhn, Ed., p. 3-20)

THE WORLD BANK. Poverty headcount ratio at $\$ 2$ a day (PPP) (\% of population). 2011. Retrieved from The World Bank website: < http://data.worldbank.org/ indicator/SI.POV.2DAY>. Accessed on: July 13, 2012.

UTTERBACK, J. M. Mastering the dynamics of innovation. Boston: Harvard Business School Press, 1996. (Original work published 1994)
VERGANTI, R. Design-driven innovation: changing the rules of competition by radically innovating what things mean. Boston: Harvard Business Press, 2009.

VON HIPPEL, E. The source of innovation. New York: Oxford University Press, 1995. (Original work published 1988)

WALLAS, G. The art of thought. New York: Harcourt Brace, 1926.

WEISBERG, R. W. Creativity: understanding innovation in problem solving, science, invention, and the arts.

Hoboken, NJ: John Wiley, 2006. 